一期的に手術を施行した食道偽肉腫, 肝細胞癌併存の 1 例

\author{
大阪労災病院外科 \\ 富 永春海吉川澄道清勉
}

食道偽肉腫, 肝細胞癌併存の 1 例に対し，一期的に根治術を施行し得た症例を経験し た. 症例は 72 藏男性. 嚾下障害にて来院. 食道透視, 食道内視鏡, 胸部 CTにて食道 $\mathrm{Im}$ に有茎性の腫痹を認めた．また腹部 CT，超音波検查にて肝 $\mathrm{S} 8$ に腫瘤を認めた，呼吸機 能低下のため, 非開胸食道抜去術, 肝部分切除術を施行した。患者は術後 70 力月目に, 肝細胞癌再発のため死亡した. 食道偽肉腫肝細胞癖の併存症例の報告は文献的に検索し 得なかった. 食道肝同時性重複癌症例の報告は本症例を含めると 23 例であった. 11 例は 两癌に対し手術が施行されていた，食道肝同時性重複癌症例は高齢者で肝機能障害を伴 い術前状態不良の症例が多い。しかし手術可能な症例に対しては手術を施行出来れば, 本症例の様に 5 年以上生存する例もあり，外科的治療の考慮が必要と思われた。

索引用語：食道偽肉腫, 肝細胞癌, 重複癌

\section{はじめに}

食道伪肉腫、肝細胞癌の併存例の報告はない、また 食道癌, 肝細胞癌同時性重複癌はまれであり，両癌共 に切除し得た症例は少なく, 本症例を含めると, 現在 まで文献的に 11 例の報告例をみるに過ぎない。食道偽 肉腫，肝細胞癌の合併例に対し，一期的に手術を施行 し, 術後 70 力月生存した症例を経験したので, 報告す る.

患者：72 歳, 男性.

\section{症例}

主訴：䓵下困難.

家族歴：特記すべきことなし.

既往歴：16 藏時, 肺結核。

現病歴: 平成 3 年 3 月中旬より，固形物の燕下が困 難となってきた. 近医受診し食道癌の診断を受け，精 查目的にて, 当科に入院した。

理学的所見 : 身長 $163 \mathrm{~cm}$, 体重 $46 \mathrm{~kg}$, 栄養状態は不 良. 賃血, 黄㾝を認めず, 胸腹部所見に特記すべき所 見はなかった。

入院時検查成䊧 : アルフミン $2.9 \mathrm{~g} / \mathrm{dl}$, コリンエス テラーゼ $131 \mathrm{IU} / l$, 呼吸機能 1 秒率 $49 \%$ と低栄養お よび高度の呼吸機能の低下が認められた．肝機能は正 常であり, S.C.C. $0.7 \mathrm{ng} / \mathrm{ml}$, AFP $3 \mathrm{~g} / \mathrm{ml}$, CEA $3.6 \mu \mathrm{g} /$

1999 年 4 月 28 日受付 1999 年 8 月 31 日採用 $\mathrm{ml}$ と腫瘍マーカーも正常範囲内であった. HBs 抗原 (一), HCV 抗体 $(+)$ であった.

食道造影：胸部食道 $(\mathrm{Im}) に 9 \times 4 \mathrm{~cm}$ の表面不整な 腫瘤を認めた，可動性はなく，食道内腔をほぼ閉塞し ていた（图 1).

食道内視鏡：門歯より $32 \mathrm{~cm}$ に表面不整な腫瘤を 認めた. 生検にて平滑筋肉腫が疑われた。

胸部 CT：胸部食道内に有茎性の腫瘤を認めた。周 囲臓器への浸潤を認めず、リンパ節の腫大も認めな かった（図 1).

腹部超音波検查 : 肝 S8 に高エコーの境界明暸, 辺 縁不整の腫瘤を認めた（图 2).

腹部 CT: 䏦 S8の腫瘤は $4 \times 2.5 \mathrm{~cm}$ 大で low densityであった（図 2).

血管造影：肝 S8 に hypervascular な腫瘤を認めた。

以上より食道癌と原発性肝癌の併存と診断した。食 道癌は A1 以下 N 0, 肝癌は T2 N0M0であり, 低栄養 と，1秒率 $49 \%$ と呼吸機能の低下を認めたため，食道 抜去, 肝部分切除の予定で手術を施行した.

手術所見：肋骨弓下切開にて開腹. 腹腔側より腫瘍 部を含む胸部食道を気管分岐部まで，食道周囲を剝離 した. 左頸部に横切開を加え頸部側よりも食道周囲を 无分に剝離し, 胸腹部食道を拢去した。後縦隔ルート にて，作成した胃管を挙上し顠部食道胃管吻合を行っ た. 超音波検查にて肝 S8 の腫場を確認後, 肝 S8 部分 

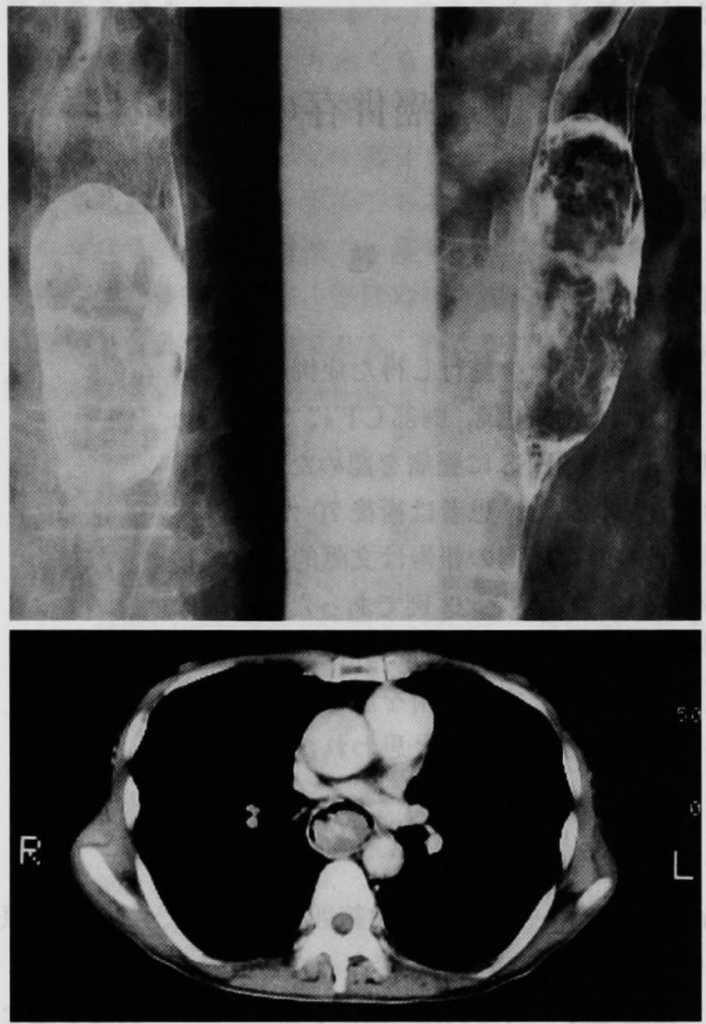

图 1 上：上部消化管造影,下：胸部 CT：食道内に腫 癖を諗めた，食道の全周性の狭窄は認めなかった。

切除を施行した。

摘出標本：食道腫瘤は有茎性で，大きさは $10.0 \times 4.0$ $\times 3.8 \mathrm{~cm}$ であり，表面不整で一部壊死を認めた。肝腫 瘤は大きさ $3.0 \times 2.8 \times 2.7 \mathrm{~cm}$, 単結節性であった. $\mathrm{Hs}$, IM0, Z0, Vv0, Vp0, Tw（一)(図 3).

病理組耤学所見：食道腫瘤は Epidermoid carcinoma with spindle-cell stroma (pseudosarcoma), sm, ie (ー)， nXであった。肝腫瘤は Hepatocellularcarcinoma, trabecular type, Edmondson II 型, $\mathrm{fc}(+)$, fc-inf (+), vp (+)であった。非癌部の肝組織は慢性 肝炎であった（図 4).

術後経過：概ね良好であり，術後54日目に退院し た. 術後 3 年目に肝両葉に出現した肝細胞癌の残肝再 発に対し TAEを施行した. 術後 70 カ月目に肝細胞癌 再発のため死亡した.

\section{考察}

今回のわれわれの症例は食道偽肉腫と肝細胞癌の併 存であった，浜辺らによると食道偽肉腫は臨床的には
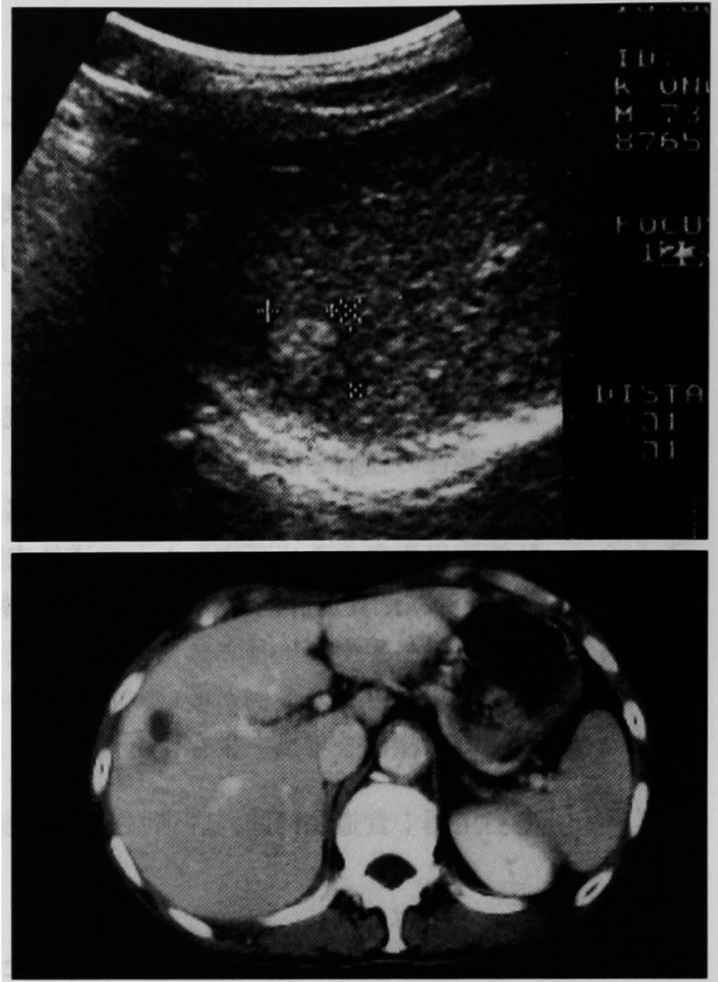

図 2 上：腹部超音波検査,下：腹部 CT：肝 S 8 にモ ザイク上状の腫瘤を認めた。

腫瘤型食道癌の 1 亜型と考えるべきであり，また積極 的な手術が必要としている゙。

食道偽肉腫と肝細胞癌の併存は文献的には検索し得 ず，食道癌と肝細胞癌の重複癌を検討した。

食道重複癌は諸家により報告されており，食道癌に 対する頻度は $3.6 \sim 12.1 \%{ }^{21-5)}$ である．食道癌との重複 癌は胃癌が最も多く，肝細胞癌との重複癌は少ない。 1972 年の中村 ら ${ }^{6} の$ 剖検例の検討では, 重複癌 1,121 例中, 食道重複癌は 104 例で, その内食道肝重複癌は 6 例 $5.8 \%$ であり，重複癌中 $0.5 \%$ であった。

文献的に記載の明らかな多重複癌を含めた食道肝同 時性重複癌は，本症例を含めると 23 例であった. 全例 が男性で年龄は 67.0 藏 (45〜83 藏)であった。主訴は 12 例が嬹下困難等の食道癌が原因と思われるもので あった. 11 例は主訴がなく，肝機能異常にて経過観察 中にまず肝細胞癌が発見されていた．17例に肝機能障 害を哂めた。

食道肝重複癌に限らず重複癌はどちらかの癌が進行 しており根治が望めなければ手術不能となる場合が多 

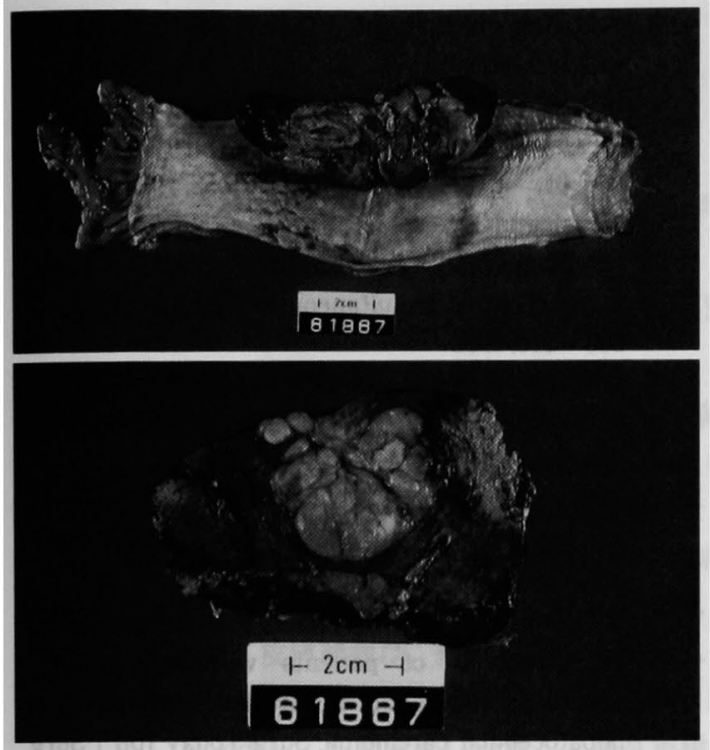

图 3 上：食道切除標本，下：肝眼切除標本

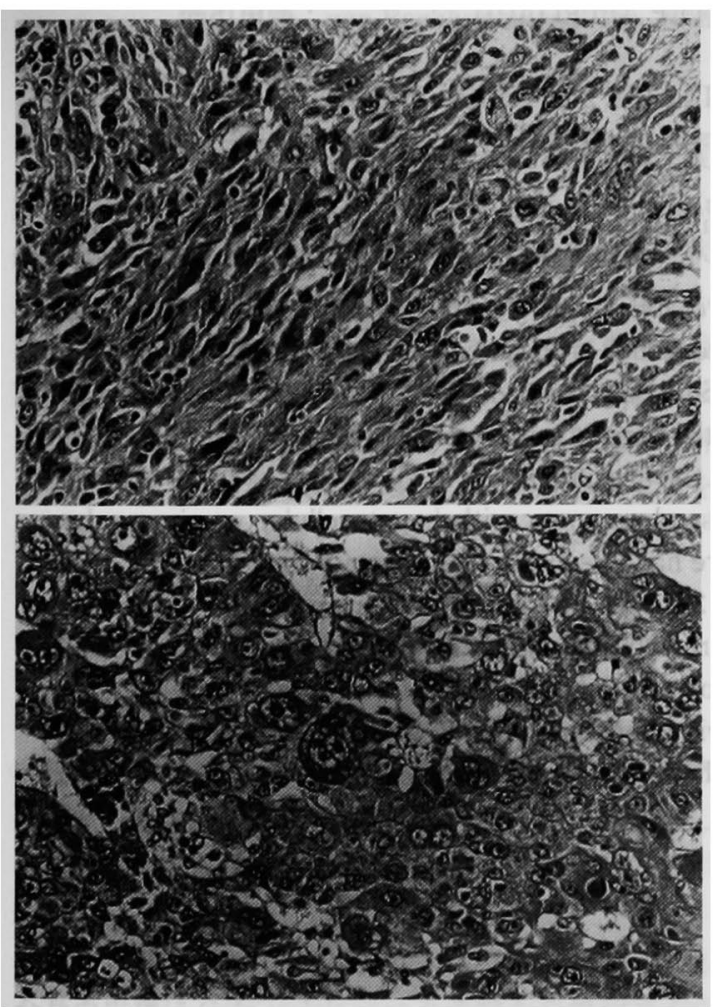

图 4 病理組織学的所見（HE 染色，20×3.3） 上：食道の腫瘍，下：肝䑏の腫瘍
い，一方食道癌は高齢者で術前状態不良な例が多く， 肝細胞癌は肝障害を伴うことが多い，従って全身状態 不良な症例に対しては，手術以外の治療法の選択，食 道癌に対しては放射線照射や化学療法, 肝細胞癌に対 しては PEIT, MCT, TAE 等の治療を考慮する必要 があるであろう。また手術を施行する場合は，慎重な 術式の検討が必要であろう。自験例は 72 歳と高龄で, 1 秒率 $49 \%$ と低下していたため開胸操作は不可能で あり，食道癌は $\mathrm{A} 1$ 以下 N0 と考えたために，非開胸食 道抜去術を施行し, 肝病変に対しては部分切除とした.

両癌に対し手術施行された症例は 23 例中 11 例で あった，图 5 に食道癌肝細胞癌同時性重複癌の生存曲 楾を示す，手術不能症例は全身状態が不良であり，癌 が進行しているため, 当然予後は不良であるが, 雨癌 共に手術を施行できた症例は手術非施行例よりも予後 は良好である，手術施行できれば予後は改善出来ると 思われる。

両癌手術症例中 4 例が死亡している．1例が䋖合不 全が原因で死亡7.２例が食道癌の再発が原因で術後 13 力月目, 18 力月目でそれぞれ死亡している899. 本症 例は肝細胞癌の再発で死亡しているが, 70 力月生存し た. 生存例中 2 例で肝細胞癌が再発しているが。 TAE, PEIT が行われており, 術後 12 カ月, 22 力月そ

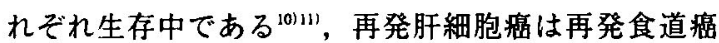
より手術以外の種々の治療法があるため, Momita ら の報告している様に食道癌肝細胞癌同時性重複癌の予 後は食道癌に，より規定されると思われる.

\section{結 語}

食道偽肉腫，肝細胞㿋併存例に対し，一期的に根治 術を施行し得た症例を経験した，われわれの症例は食

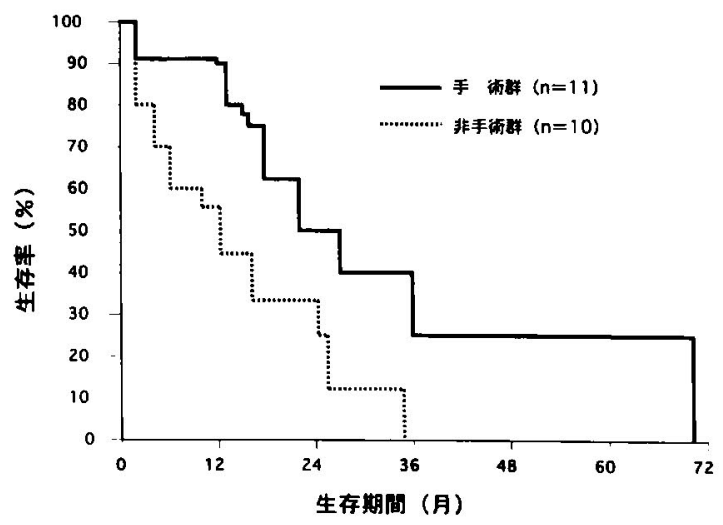

図 5 食道肝細胞满同時性重復㾟症例の生存曲線 
道偽肉腫の再発がなく，また肝細胞癌の再発を認めた が, TAEが有効であり 70 カ月生存した。

\section{女献}

1）浜辺 豊, 佐藤美晴, 小谷陽一他：肉腫样組䅧成分 を伴った令道癌について．外科治療 $52: 255-$ 264,1985

2）阿保七三郎, 三浦秀男, 工藤 保他：日本における 食道と他戥器の重襘癌について。 日消外会誌 $13: 377-381,1980$

3）富田雅義，西尾正道，加賀美芳和他：食道輹におけ る重複㾮症例の検討。日放線腫瘍会誌 $1: 239-$ 244, 1989

4）村山 公, 佐藤博信, 河口忠彦他：食道重複癌 26 例の検討. 外科 $52: 71-75,1990$

5）山本雅一, 吉田 操, 村田洋子：食道癌における重 複癌症例の検討。日消外会誌 $23: 2723-2727$, 1990

6）中村恭二, 相沢 幹：組み合わせよりみた重複癌 の検討. 潘の臨 $18: 662-666,1972$

7) 東根達也, 田村 直, 金尾 丹他：臨床診断のつい
た食道癌・肝細胞癌の 1 重複例と本邦報告 17 例 の文献的検討. 外科 $54: 1012-1015,1992$

8）横山康弘, 植田 守, 平田 哲：Estrogen Receptor 陽性食道癌と肝硬変併存肝癌の同時性重椱癌 の一例. 北海道外科誌 $34: 56-58,1989$

9) Nagahama $T$. Goseki $N$, Kato $S$, et al : Esophageal carcinoma and coexisting hepatocellular carcinoma resected simultaneously. Arch Surg 131 : 208-210, 1996

10）岸健太郎，左近賢人，西嶌染一：口蓋垂癌術後に診 断された肝癌。食道癌の同時性重複癌の 1 例.日臨 外医会誌 $58 ： 685-689,1997$

11）本田五郎，山崎信保，嶌原康行他：食道㿋上肝細胞 癌の同時性重複癌の 1 切除例. 日消外会誌 30 ： 759-763, 1997

12) Morita M, Kuwano H, Toh Y, et al : The clinical characteristics of patients with synchronous squamous cell carcinoma of the esophagus and hepatocellular carcinoma. Surg Today Jpn J Surg $24: 803-808,1991$

\title{
A CASE OF ESOPHAGEAL PSEUDOSARCOMA AND HEPATOCELLULAR CARCINOMA RESECTED ON ONE-STEP APPROACH
}

\author{
Harumi TOMINAGA, Kiyoshi YOSHIKAWA and Tsutomu DOUSEI \\ Department of Surgery. Osaka Rosai Hospital
}

This paper reports case of esophageal pseudosarcoma and hepatocellular carcinoma which were radically resected on one-step approach.

A 72-year-old man was seen at the hospital because of dysphagia. Fluoroscopic study of the esophagus, esophagoscopy, and chest CT scan revealed a pedunculate tumor in the Im of the esophagus. Abdominal CT scan and ultrasonography revealed a tumor in the liver (S8). Because of decreased respiratory function, nonthoracotomic blunt dissection of the esophagus and a partial hepatectomy were performed. The patient died of recurrence of hepatocellular carcinoma 70 months after the operation.

No previous reports of association of esophageal pseudosarcoma with hepatocellular carcinoma have been seen in the literature as far as we could review. There have been 23 cases of synchronous double cancer of the esophagus and liver, including this case. In 11 out of 23 cases, operation was performed for both cancers. Synchronous double cancers of the esophagus and liver are common in elderly patients, are often associated with impaired liver function. and many patients are in poor general condition before surgery. However, if operation is performed for operable patients. long-term survival for more than 5 years like this case can be expected. In the treatment of the disease, surgical approach has to be considered. 